\title{
THE LIMITS OF TRANSLATING POSTCOLONIAL EXPERIENCE INTO A FOREIGN CULTURE ${ }^{1}$
}

\author{
N. Berrin Aksoy ${ }^{2}$
}

\begin{abstract}
In this twofold study, I will focus on the exilic/ diasporic Nigerian-born black British author Ben Okri as a postcolonial author reflecting the issues of postcolonial literature in his novel The Famished Road from a translational point of view. I will first discuss the qualities of the exilic/diasporic experience in postcolonial literature in terms of theme, style and language use; language is the key element in postcolonial literature which reflects the hybridity of cultures and the hybridity of the language used in postcolonial texts, which is closely associated with the translation challenges of a postcolonial text into a culture which is alien to postcolonial experience. My aim in this study firstly will be to discuss whether the novel The Famished Road which displays the characteristics of a postcolonial text in terms of style, themes and the hybrid language use avails itself with all its generic qualities in the Turkish translation and creates the same effect and impressions on the Turkish reader in terms of voicing the postcolonial experience as it has on the English reader and, secondly, how the generic qualities are transferred into the language of a culture which does not possess a similar literary or cultural medium.
\end{abstract}

Key words: Postocolonialism, translation challenges, foreign culture, Ben Okri

Postcolonial turn in literary and translation studies has led the way to the investigation of how the themes of postcolonial experience are expressed, conveyed and recreated in translating postcolonial texts into a foreign language. The purpose of this study is to explore how one of these postcolonial themes, and the trauma it brought about, are represented in a non-European language, Turkish, which belongs to a culture which does not have any colonial or postcolonial experience of the European kind. Turkish readers have met with the postcolonial turn and postcolonial subjects in its literature through translations only quite recently. In this study, I will examine The Famished Road by Ben Okri which I translated some years ago, in relation to the issues involved in the translation of a postcolonial novel that engages itself with the themes of exile,

1. This article is a largely revised version of the paper "Ben Okri and the limits of recreating the exilic experience in translation" submitted to Congrés Internacional Literatura i Exili, 232425 d'octubre de 2019, Universtat Rovira i Virgili.

2. Professor, PhD at Atılım University, Department of Translation and Interpretation, Ankara, Turkey, e-mail: berrin.aksoy@atilim.edu.tr, ORCID: 0000-0001-5716-1962. 
trauma, identity and economic neglect and underdevelopment that are mainly caused by devastations of colonialism. These qualities urge the translator to work on the translation process with a postcolonially-based approach which requires in the translation to highlight elements of language and style that the author of the original text uses to express the postcolonial themes. The novel was translated into Turkish in 2000, and published the same year by İmge Kitabevi, Ankara, Turkey. Hence, there is a time gap which allows me as the translator to assess the translation from a more contemporary perspective.

It may be worthwhile to begin by giving a brief information of Turkish literary polysystem which is the target system in this context. Contextual information of this kind will clarify the role and the images of translations in the Turkish literary polysystem and the conditions that affect the selection of The Famished Road for translation and its final reception. Turkish readers were introduced to world literature from Translations in the early years of the Republic which was founded in 1923 when the polysystem initially consisted of court literature models of the Ottoman times and people's oral literature dating back to the same times and even before. With the founding of modern Turkey, translation activities began to be organized by the state to promote affinities with the world literature, mainly with the Western works that contributed to the formation of European Humanism. Inspired by these translated models and together with the employment of our classical Ottoman literary tradition (especially in poetry and in verse form) and Anatolian folk literature modern Turkish literature flourished, which has now in the 21st century, a thriving, rich and varied identity, with a wide reading public composed of a very young population. Considering Turkey's historical past as an empire composed of many nations, Turkish reading public has always maintained a curiosity towards different and foreign cultures. Nevertheless, the situation of the Turkish reader of Ben Okri is rather different from that of his English reader who is familiar with the colonial experience and its manifestations in the book. For the Turkish reader, the translation is above all, very informative about the African culture, and the history of its colonial past, but it does not ignite any familiarity in terms of postcolonial experience and the themes it creates in literature.

Before delving into the issues of the translation analysis for the purpose of studying how the exilic elements in the book are translated, it may be worthwhile to discuss some of the qualities of The Famished Road as a postcolonial novel reflecting the exilic experience of its author. The book is culturally grounded in Nigerian myths and motifs as in the case of the narrator Azaro's being an Abiku child,which means a spirit-child in African folklore. The course of action evolves around him and the microcosm of his environment reflected by the author in the myths, beliefs and cultural practices of the African milieu. Okri's employment of myths in order to fictionalise reality of the situation in Nigeria and at the same time universalizing the general condition of the human 
self in the post-colonial time in a metaphorical and subtle way along with the hybrid language he chooses to use, situate the book within postcolonial sphere. Abiku, or the spirit child Azaro, may just be a concept in which West-African societies have taken refuge against the enviromental problems and dire living conditions such as the raids of mosquitos and the diseases caused by lack of sanitation. However, Okri uses this legendery folktale element of the Abiku child as a metaphor to create an otherworldly and imaginary effect on the reader and an understanding of the African condition. This effect is manifested by the spirit-child Azaro who is in a perpetual exile from the other world and is living the experience of the human condition in a miserable environment. Azaro's experience of this world of Africa, his spiritual disillusionment, sorrow and pain is manifested in a web of criticism. The criticism is about the political and economic conditions in Africa caused by years' long sufferings due to bad management and devastation caused by colonialism. Ben Okri's treatment of the subject matter and the literary devices he employs shed light in a metaphorical way, on the political and economic realities in African nations as well as the lost individual trapped in the mystery of the road of life which has no limits to deplete and devour all the potentials of the African people. All these elements in the novel suggest Ben Okri's preoccupation with his native country and his own situation at the crossroads of Britain and Africa, hence his implicit experience of exile.

The roads seemed to me then to have a cruel and infinite imagination. All the roads multiplied, reproducing themselves, subdividing themselves, like snakes, tall in their mouth, twisting themselves into labyrinths. The road was the worst hallucination of them all, leading towards home and then away from it, without end, with too many signs, and no directions. The road became my torment, my aimless pilgrimage, and I found myself merely walking to discover where all the roads lead to, where they end (Okri, 1993, pp. 114-115)

\section{Elsewhere,}

Then, suddenly, with the sun burning itself into evening, with so many people around, everyone active, everything moving, I was overcome with a strange panic. I couldn't see a single familiar face in that jostling universe. And then just as suddenly, in flashess of lightness and dark, I begun to see Mum everywhere. I saw her writhing in the basin of eels. I saw her among the turtles in the plastic buckets. I saw her among the amulets of the sellers of charms. I saw her all over the market, under strange eaves, in the wind that spread woodamoke and rice-chaffs; I felt her everywhere, but I couldn't break the riddle of the market's labyrinths where one path opened into a thousand faces, all of them different, most of them hungry in different ways (Okri, 1993, p. 162). 
In the diabolical heat of that afternoon six illegitimate sons of minor warlords, whom I first thought were minotaurs, enacted a battle of ascendancies. They fought near the burnt van. No one came to seperate them. They lashed at one another with long sticks, clubs, and whips. They all looked alike. They were the interchangeable faces of violence and politics (Okri, 1993: 192)

These excerpts portray the African situation through Azaro's eyes, back to back with the general feeling of devastation and loss of humans in typical native African metaphors and folktale symbols. Ben Okri's attempt at treating the African situation in connection with the universal situation of mankind in a dream-like "Yoruba folklore" (Obumselu, 2011, p. 3) narrative .

According to Ben Obumselu (2011), Yoruba folklore establishes the main outline of Okri's portrait of Azaro. Obumselu writes the following about how Okri uses literature to voice the postcolonial experience in The Famished Road:

But in filling in the details, of the music-filled paradise which is Azaro's spiritual home, of the mazes, labyrinths and lonely crowds which are the backdrop of daily life, of intolerable poverty and misery in city slums, and of disgust and anguish as existential responses to the human condition, Okri consults the folklore of many lands, the tradition of West African political novel, and contemporary world literature (Obumselu, 2011, pp. 2-3).

Adnan Mahmutovic (2010) underlines Azaro's symbolical place as an agent of portraying the postcolonial experience of Africa in general, and of an African in particular, while also portraying the "history of the African territory on the verge of becoming the modern, decolonized nation-state of Nigeria. 'our road was changing. Nothing was what seemed anymore"" (428). Azaro further claims, "I knew we were in the divide between past and future. A new cycle had begun, an old one was being brought to a pitch" (256). "This pitch is the highest point of material and spiritual famine of the colonized people" (Mahmutovic, 2010, pp. 2-3)

With respect to the language used in The Famished Road, as in most postcolonial writing, it is manifestly hybrid, meaning that it involves multiple linguistic and cultural systems. The hybridity of the book lies not only in its language that reflects the linguistic and cultural elements of Nigeria, but also in the capacity of Okri of melting a West African postcolonial novel with the existentialist tone of modern European novel, written in the colonizer's language which is English.

Professor Paul Bandia, one of the developers of postcolonial translation as a field of study, explains this idea as following: 
In the postcolonial context, when African and European discourses merge, the difference of perception of socio-cultural interactional norms and values and social situations that exists between the traditional African society and its European counterpart makes for a peculiar African discourse-type in European languages. Discoursal indirectness as practised in traditional Africa, is often emulated by Euro-African writers resulting in a peculiar discourse-type. By indirectness we mean the strategy of making a point or statement in a roundabout manner, through circumvention, calculated delays, pausing and so on (Bandia, 2003, pp. 132-133)

According to Bandia, discoursal indirectness shows the oratory skills of the Africans using a language full of symbolism and imagery. Hence, Bandia asserts that African writers often attempt to reproduce these rhetorical skills in their Europen texts, as seen in The FR where the opening passage of the book runs like an ancient traditional African folk story:

In the beginning there was a river. The river became a road and the road branched out to the whole world. And because the road was once a river it was always hungry.

In that land of beginnings spirits mingled with the unborn. We could assume numerous forms. Many of us were birds. We knew no boundaries. There was much feasting, playing and sorrowing. We feasted much because of the beautiful terrors of eternity. We played much because we were free. And we sorrowed much because there were always those amongst us who had just returned from the world of the Living. They had returned inconsoluble for all the love they had left behind, all the suffering they hadn't redeemed, all that they hadn't understood, and for all that they had barely begun to learn before they were drawn back to the land of origins. (Okri, 1993, p. 3)

Ben Okri, in an interview he gave to the newspaper The Guardian, tells the following about how the native African magical quality of The Famished Road is embedded in his narrative style:

The Famished Road is fed by the dreams of literature. I devoured the world, through art, politics, literature, films and music, in order to find the elixir of its tone. Then it became a perpetual story into which flowed the great seas of African dreams, myths and fables of the world, known and unknown. I made up stories in the ancestral mode.......The stories my mother told me wrer elliptical and strange, and the philosophies of my father steeped in the ancient African world that was older and stranger than the Greek myths... (Okri in The Guardian.com) 
Evaluating The Famished Road from a translational aspect for the purpose of seeing how the exile theme is perpetuated in the translation, lets discuss some ideas put forward by Paul Bandia. According to Bandia, postcolonial translation theory deals with translation between dominant language cultures and minor cultures and minority contexts, including minorities in the former post-colony. Bandia asserts that:

ethno-global minorities result from experiences of migration or displacement whether forced or voluntary. The texts they produce are hybrid, like Homi Bhabba says, polylingual, multilingual, plurivocity even though they are expressed in one and the same language. It means you are expressing the text in English but the English you are expressing it becomes the medium or the matrix of expression infused with the linguistic and aesthetic specificty of African discourse. Hence, the postcolonial text that is being translated is itself a translation with a lot of foreignized elements in the original text (Bandia, 2017: conversation with Yann Le Gall and Moses Marz)

I was commissioned to translate The Famished Road from English into Turkish Initially, I was not aware of all its distinctive qualities as a postcolonial novel in terms of themes and language. The striking thing for me was the lexical and syntactic idiostyle arising from the hybrid nature of the language used by Ben Okri, which is actually the main tenent of his representation of his own exile, and so, the main problems at the beginning appeared to be: First, how to contextualise this hybrid language for the target audience due to the lack of similarity between the Turkish reader's context and that of the source text reader; and between Turkish literary polysystem where exilic literature is still on the periphery and even so with very different connotations; and secondly and of course in connection with the first, how to deal with the Africanness in terms of the cultural and tribal qualities carried over into English. With regard to those translation challenges, extensive research had to be carried out about Ben Okri's peculiar style and the hybrid quality of the language and its cultural manifestations. The translation had to be carried out in such a way that the foreignness in the original text should be preserved and carried over into Turkish in a manner that did not counteract mainstream tendencies in the domestic system in terms of language use and context. Thus, the translation strategy employed in the translation of The Famished Road may best be explained by the methods proposed by Susanne Klinger (2018) in her article named De/Recolonization in Translation. In general, direct translation method was preferred for instances where I could find literal and semantic equivalances for general expressions, dialogues or descriptions. On the other hand I adopted an exoticizing approach (see Klinger 2018) which is described by Klinger as: 
[...] these foreignizing strategies can be either alienating (foreignizing strategies that challenge the domestic canon) or exoticising (foreignizing strategies that comply with domestic stereotypes about the foreign culture). Exoticising strategies... can be either (i) intentional as postcolonial writers might deliberately play with Western stereotypes (see also Carbonell i Cortés, 2002, p.9) or even deliberately comply with these stereotypes to a certain degree in order to get published and read in the West, or (ii) unintentional, an inevitable side-effect of a text that does not want to deny its foreign origins [...] a translated text [...] that is foreignizing in as such as it avoids to "culturally transplant" the text in its entirety [...] will always be exoticizing to some extent as by definition it foregrounds the foreign, constructing the source culture as "other" (ibid., p. 148).

Foreignization strategies have been used in order to comply with domestic streotypes about Africanness and yet, display these qualities in The Famished Road and themes that concern them while at the same time produce a translation which reflects the universal and Western canonical qualities of the original. Hence, for example for the excerpt on page 3 which I have given above and which is the opening and key paragraph of the book, I decided to choose a style which was used in the oral story-telling tradition of ancient Turkish folkstories and tried to stay loyal to the qualities of the paragraph and its ancient nonWestern, African oral story narration by drawing similarities with ancient Turkish folkstories. In terms of grammar I used simple past tense in Turkish which stands for an action that takes place in the past, continued for sometime and stopped:

In the beginning there was a river/ başlangıçta bir nehir vard1, nehir yol oldu ve yol da tüm dünyaya dalbudak sardı (Okri, 2000, p.5).

For the expression branched, there is a similar expression of expansion especially used in stories "dalbudak sarmak" which is a metaphor of the branches of a tree.

In the case of the use of an adverb of place at the beginning of the second paragraph in the source text, I could construct the equivalent pattern since it exists in Turkish and is a recurring use in our folk stories.

Elsewhere, the unfinished long sentences divided by commas were also easy to handle since similar structures were used in Turkish, too.

I believe the Africanness as an outlet for the expression of some degree of longing of the native culture and country in the book is conveyed satisfactorily into Turkish. This ancient storytelling mode looks incongrious for the Western narration but smoothly rings the bells in the Turkish reader of its African and magical qualities. 
Paraphrasing (Klinger, 2018) is another strategy which keeps the source text's implications and foreignness but at the same time brings the text to the target reader. Especially for some local cultural artefacts such as food, crockery and household goods such as eba, ogogoro, paraphrasing within the sentence was the most suitable method since it did not interrupt the fluency of the narration.

Borrowing was another strategy for some untranslatable objects such as the names of some plants and trees as iroko, obeche and I prefered to borrow them instead of deleting or replacing by some familiar plant names in Turkish. I wanted to attract the geographical distance between English as the medium of the book and the plants in Nigeria that are totally different from the plants in Britain or in Turkey. These two strategies which may be called selective reproduction are an exoticising strategy when these selectively reproduced foreign language words are understandable in their context by the target reader (Klinger, 2018, p.150).

Distancing through literalness or word for word translation (Klinger, 2018, p. 151 ) is another strategy that serves the recreation of the foreignness of the text to mirror its peculiar hybrid quality. Especially in long descriptions of Azaro's interpretations of his surroundings and the people inhabit it and in metaphorical and imagery loaded expressions reflecting the hybrid quality of a postcolonial text, syntactic and lexical literaliness served better. Such as:

On many of those nights, in my childhood hour, Mum told me stories of aquamarine beginnings. Under the white eye of the moon, under the indigo sky, in the golden lights of survival in our little room, I listened to the wisdom of the old songs which Dad rendered in his cracked fighting voice. Mesmerised by the cobalt shadows, the paradoxical ultramarine air, and the silver glances of the dead, I listened to the hard images of joy. I listened also to the songs of work and harvest and the secrets of heroes.

Outside, the wind of reccurence blew gently over the earth. (Okri, 1993, p.183)

Bu gecelerin çoğunda, çocukluğumun saatinde, annem bana mavimsi yeşil başlangıç öyküleri anlatırdı. Ayın beyaz gözü,indigo gökyüzü altında, küçük odamızda var olmanın altın ışıntıları içinde, babamın çatırdayan dövüşken sesiyle söylediği eski şarkıların bilgeliğini dinledim. Kobalt gölgeler, birbirine aykırı ultramavi hava ve ölülerin gümüş bakışlarıyla büyülenmiş olarak sevincin güç imgelerine kulak verirdim. Çalışmanın, hasatın ve yiğitliğin gizemleri üzerine yapılmış ezgileri de dinledim.

Dışarda tekerrür rüzgarı usulca esiyordu yeryüzünün üstüne (Okri, 2000, p. 216) 
I translated the above passage grammarwise and syntactically as literally as possible because I felt that it was one of the best expressions of the sense of disconnection from the actual place and a longing for the home as represented in a maze of imagery and metaphors. I believe the translation managed to recreate the meanings in the original.

Ennoblement (Klinger, 2018, p.151) was the next strategy I chose to employ when I felt the need to draw the attention of the reader to a particular foreign issue that stands for the meanings of the source text. For instance for the word 'wisdom' I used a heavier term 'bilge', or for the expression 'the wind of recurrence' I used an archaic word 'tekerrür' to highlight its figurative significance.

Although The Famished Road deals with themes of our modern times, its creative portrayal of African folkloric discourse and spiritual and magical Africanness that moves along instances of magical realism and fantasy without losing its touch with political and postcolonial reflections make the translation process a very challenging one. Another important element that poses a challenge is that there is difference between the expectations of the target reading audience and the source audience, or rather the readers who are contextually familiar with postcolonialism and those who are not, that is the target Turkish audience. Target audience is engaged with the translation at all cases, as a novel representing a new and foreign experience in terms of language and themes, whereas for the source reader, the postcolonial experience is shared.

It is hoped that, this paper will shed some light on the strategies employed to deal with the above challenges and may pave the way for further discussions on translating postcolonial novels with all their implications, meanings and artistic qualities to foreign cultures and readers.

\section{References:}

Bandia, P. (2003). Postcolonialism and translation: the dialectic between theory and practice, Linguistica Antverpiensia, (Special Issue: Translation as Creation: the Postcolonial Influence), II, 129-142.

Bandia, P. (2017). Postcolonial translation theory and minor literatures.

Professor Paul Bandia in Converstaion with the RTG Minor-

Cosmopolitanisms. Retrieved from http://uni-potsdam.de.

Klinger, S. (2018). De/Recolonization in translation. Selçuk Üniversitesi Sos. Bil. Ens. Der. (40), 146-160.

Mahmutovic, A. (2010). History as the road of existential struggle in Ben Okri's The famished road (1993). JPCS, 1 (3\&4), 948-1853. (Electronic). Retrieved from www.jpcs.in 
Obumselu, B. (2011). Ben Okri's The famished road: a re-evaluation Tydskr. letterkd, 8 (1). Pretoria. Retrieved from www.scielo.org.za

Okri, B. (2016). The Famished Road was written to give myself reasons to live in. www.theguardian.com/books

\section{Sources:}

Okri, B. (1993). The Famished Road. Doubleday, New York: Anchor Books.

Okri, B. (2000). Aç Yol. (B. Aksoy Trans.). İmge Kitabevi, Ankara. (Original work published 1993) 